\title{
Perspectives
}

\section{Revision in Second Language Writing: What Teachers Need to Know}

\section{Khaled Barkaoui}

This article reviews theories and research on revision in second-language (L2) writing. It examines how and what L2 writers revise, compares the revision practices of skilled and unskilled $L 2$ writers, and suggests instructional practices to help learners improve their 22 revision skills.

Cet article passe en revue les théories et la recherche portant sur la révision de l'écriture en langue seconde. Nous étudions ce que révisent les auteurs en L2 et comment ils le font, comparons les pratiques des auteurs habiles à celles des auteurs moins expérimentés, et proposons des stratégies pédagogiques visant l'amélioration des habiletés de révision chez les apprenants en langue seconde.

Revising is an essential component of skilled writing. Yet it seems to play a limited role in the writing of many novice second-language (L2) writers. These writers may find it easier to generate ideas than to revise what they have written in relation to task requirements and their writing goals and audience. Consequently, many fail to revise frequently, extensively, or skilfully. This article reviews research on revision in L2 writing in an attempt to understand how and what skilled and unskilled L2 writers revise, factors influencing their revision practices, and how instruction can help them improve their revision skills.

What is Revision?

Literally, revision means "seeing again" (Reid, 1993, p. 233), revisioning or reseeing the text. Technically, revising refers to any evaluation and/or change made at "any point in the writing process" (Piolat, 1997, p. 189). Revising is an ongoing, recursive, problem-solving process. Good writers seem to revise at all stages of the writing process as they generate, evaluate, reformulate, and refine their writing goals, ideas, plans, and texts in their attempt to discover and approximate intended meanings (Faigley \& Witte, 1981; Sommers, 1996; Witte, 1985; Zamel, 1982). The ability to revise is significant because it helps writers reshape their thoughts, discover and reconstruct meaning, and improve their texts (Reynolds \& Bonk, 1996). Consequently, virtually all writing theories and models emphasize the central 
role of revision in both the process and outcome of writing development (Bartlett, 1982; Huot, 2002; Reynolds \& Bonk; van Gelderen, 1997).

Several models have been proposed for revision, mostly for first-language (L1) writing. These models can be classified into two categories: taxonomies that describe revision outcomes and models that describe the revision process. One product-focused model is Faigley and Witte's (1981) model of revision changes, which consists of two types of changes, surface changes that do not affect the meaning of the text and text-based changes that do affect the meaning of the text. Surface changes include spelling, punctuation, and grammar, as well as meaning-preserving changes such as addition, deletion, substitution, and reordering. Text-based changes include macrostructure changes that alter the gist or overall meaning of the text and microstructure changes that modify the meaning of the text but not its overall meaning or gist.

There are several process-oriented models of revision (Bartlett, 1982; Hayes, Flower, Schriver, Stratman, \& Carey, 1987; Scardamalia \& Bereiter, 1987). Scardamalia and Bereiter suggested a model that includes three mental operations: (a) comparing intended and written texts; if a disagreement is detected, (b) a diagnose operation is initiated to identify the nature of the disagreement; the writer then (c) operates to reduce the dissonance by changing his or her text and/or writing plan and goals. These changes may be made either on paper or in the writer's mind.

Hayes et al. (1987) proposed a more elaborate model that incorporates earlier outcome- and process-oriented models. This model consists of four basic processes: (a) task definition, (b) evaluation, (c) strategy selection, and (d) modification of the text. Task definition consists of specifying the revision goals (e.g., improve clarity or elegance), the characteristics of the text to be examined (e.g., local or global aspects), and the means to reach the goals (e.g., examine the text in one or several passes). Evaluating both plans and the written text may lead to detection (i.e., the reviser feels that there is a problem but cannot identify it) or to actual diagnosis (i.e., a well-defined representation of a problem, e.g., This word is misspelled). The ability to detect or diagnose a problem depends on the writer's expertise and the nature of the problem (e.g., style, spelling problems). The reviser can then select one of two types of strategies depending on the initial problem representation: strategies that modify or control the revision process itself (ignore the problem, delay its resolution, or search for more information to clarify the it), or strategies that modify the text (rewrite the text so that the ideas, but not the written text itself are preserved; or revise the text, for example, by changing what needs to be changed and preserving what can be preserved). Based on their knowledge of the communicative aims and the various linguistic levels of the text (i.e., ends), writers use various operations such as insertion, replacement, or deletion (i.e., means) for modification of the text. For ex- 
ample, when a writer recognizes that the audience may not have the appropriate background knowledge to follow the text's major claims, the chosen strategy may be to create new examples and add supporting evidence to make the text more understandable (Schriver, 1990). It should be noted, however, that the use of these processes depends on several factors such as the writing task, the ability of the writer, and other contextual constraints (e.g., time).

\section{Revision in L1 and L2}

Although several empirical studies on L1 writers' revision practices have been reported, there are few such studies in L2 writing. Most of what we know about L2 learners' revision practices has come from three types of studies: those that examine students' L2 composing processes (Raimes, 1987; Zamel, 1982); those that compare L2 learners' revision processes and outcomes in the L1 and the L2 (Hall, 1990); and those that compare the revision practices of skilled and unskilled L2 writers (Porte, 1996, 1997). These studies use think-aloud protocols to examine writers' revision processes and holistic scores to assess the quality of their revised texts. This article reviews only studies that have specifically examined revision practices, that is, studies in the last two categories.

In terms of differences between revising in the L1 and the L2, Roca De Larios, Murphy, and Marin (2002) summarize research indicating that writers revise more and focus more on linguistic aspects when writing in the L2 than in the L1 because they "have to intensify their efforts to make their texts reflect their writing goals" (p. 34) and/or because they lack familiarity with the L2 material. Hall (1990), on the other hand-comparing the revision processes of advanced L2 learners in their L1 and L2-found that students employed similar processes in terms of level (word, phrase, etc.), type (e.g., substitution, deletion, addition), stages (e.g., planning, drafting), and purposes (e.g., informational, grammatical) of revision. However, Hall also found some differences between revising in the L2 and the L1; L2 revisions were more time-consuming and numerous, and some revising strategies (e.g., underlining words or phrases to be revised later) were unique to L2 writing. Overall, Hall's findings seem to suggest that advanced L2 writers are "capable of utilizing a single system of revision across languages" (p. 56). It thus seems that as their L2 writing proficiency develops, L2 writers learn not only the linguistic conventions of the L2, but also how and when to transfer revising strategies flexibly across languages.

Revision Practices of Skilled and Unskilled Writers

Another line of research has examined the revision practices of good and poor L1 and L2 writers. This research suggests that expert and novice writers differ in terms of how they see revision; their audience awareness; how 
much, when, how, and what they revise; and the effects of the revisions they make. The following paragraphs summarize the main findings from this strand of research in both L1 and L2 writing (Bartlett, 1982; Daiute, 1985; Faigley \& Witte, 1981; Hayes et al., 1987; Matsuhashi \& Gordon, 1985; Reynolds \& Bonk, 1996; Schriver, 1990; Sommers, 1996; van Gelderen, 1997; Wallace \& Hayes, 1991; and Witte, 1985, for L1 research; Hall, 1990; Krashen, 1984; Roca De Larios et al., 2002; Porte, 1997; and Victori, 1999 for L2 research). It should be noted that although the differences between skilled and unskilled writers are presented as dichotomies below, each aspect should in fact be understood as a continuum along which novice writers develop to attain expertise in (L2) writing.

1. Revision beliefs. Skilled writers distinguish between revising and editing, seeing the former as a holistic, ongoing, and recursive process to change and reshape their texts in relation to their overall writing goals and purposes. Novice writers, in contrast, do not distinguish between editing and revising; they tend to view revision as a separate stage at the end of the writing process that involves only cosmetic operations such as grammatical correction, adherence to the formal conventions of writing (e.g., correct spelling), and the improvement of text appearance.

2. Audience awareness. Skilled writers are more concerned with their audience when writing and revising. They tend to spend more time thinking about the effect they have on their reader, how they wish to present themselves to the reader, what background knowledge the reader needs to have to comprehend their text, and what may interest the reader. Novice writers, by contrast, tend to be tied to the topic and to spend less time thinking about their reader.

3. Revision time and frequency. Good writers tend to revise more frequently and to use early drafts for the creation, shaping, and exploration of ideas and relationships, postponing stylistic, grammatical, and lexical concerns until the final stages of composition. By contrast, poor writers revise little and often only at the final-draft stage.

4. Revision processes. Skilled writers tend to reread and assess their texts at multiple levels and for multiple purposes (e.g., retrieve new ideas, evaluate form and content); to use a sophisticated repertoire of revision operations (e.g., substitution, addition, and reordering) to manipulate textual conventions; to use addition of ideas as one of their recurrent revision patterns; and to switch effectively between sub-processes (e.g., generate, evaluate) and strategies (e.g., compare, diagnose, operate) in the light of their writing goals and plans. Less skilled writers, by contrast, often fail to regulate their composing and revision processes effectively. They tend to be continually interrupted by editing problems that bear little relation to substantive meaning; to use a limited set of revision strategies at the word or sentence level; to lack strategies to 
handle global problems; to revise one element (e.g., sentence, idea, word) in isolation from other elements of the text, failing to check reformulations against surrounding text; and to be afraid to reread their texts lest they come across mistakes beyond their reach to correct.

5. Revision focus. Skilled writers revise across a wide range of levels. They tend to consider both global (e.g., organization, style, interpretability, content) and local (e.g., word, phrase) aspects of their texts; to attend more often to rhetorical and organizational issues; and to make a larger number of changes that substantially alter the meaning of their text. Less-skilled writers tend to restrict their attention to the micro-level (single word, within- and between-sentence); to correct only local or surface mechanical, grammatical, and lexical problems; and to ignore macro-level revisions such as altering the content or substance of their text.

6. Revision outcomes. Skilled writers tend to improve the text from the reader's perspective and transform writer-based prose into reader-based prose. Even when they do less revising, skilled writers often produce texts that are superior in quality to those of unskilled writers because of the quality and kind of planning and pre-textual revision they do. Novice writers, by contrast, often overestimate the comprehensibility of their texts; produce writer-based prose; fail to produce meaningful organizational and rhetorical changes to their texts; and may introduce changes that make the text weaker instead of improving it.

\section{Factors Affecting Learners' Revision Practices}

Why do skilled and unskilled L2 learners revise as they do? Various explanations have been proposed to account for L2 writers' revision practices. One explanation relates to learners' L2 proficiency. Unskilled L2 writers often have a limited knowledge of the L2 linguistic conventions and of how texts work to convey an intended meaning and to achieve a particular goal in a specific context (Bartlett, 1982; Piolat, 1997; Roca De Larios et al., 2002; Victori, 1999). Kobayashi and Rinnert (2001), for example, found that L2 learners' ability to detect and address problems in their L2 texts was significantly related to their L2 proficiency and L2 writing experience. Moreover, the ability to detect problems in writing seems to develop faster than the ability to correct them (Hayes et al., 1987; Roca De Larios et al., 2002). Thus students' revision practices at a particular time reflect their writing development. As they become more acquainted with the language itself, its culture, and readers' expectations for text content and structure, L2 writers are likely to improve in their audience awareness, global revision skills, and ability to reflect on their own writing.

Second, learners' beliefs about the nature and importance of writing and revision in the L1 and L2 can affect their revision practices. For example, 
learners who believe that the ability to write is an inherent talent or gift (inspiration) tend to exert little effort and to resist revision. In addition, unskilled writers often are not aware that writing requires deliberate effort and personal commitment to the task (Bartlett, 1982; Chenoweth \& Hayes, 2001; Hayes et al., 1987; Piolat, 1997; Roca De Larios et al., 2002; Victori, 1999). Learners' revision practices are also affected by their beliefs about their writing competence. For example, learners who feel competent about writing are more likely to choose to write, to set higher goals and text-quality standards for themselves, to exert more effort on revising their writing, and to persist longer when facing difficult writing tasks (Zimmerman \& Bandura, 1994).

Learners' beliefs about writing, revision, and their writing competence are determined to a large extent by their personal, educational, and cultural backgrounds as well as their previous learning and assessment experiences (Horwitz, 1999; Porte, 1997; Silva, 1992; Victori, 1999). In fact L2 learners' learning history can affect their revising behavior significantly. As several studies have shown (Bartlett, 1982; Daiute, 1985; Porte, 1997; Roca De Larios et al., 2002), poor revisers often have had limited opportunities to read and write; have not been taught how to revise; have rarely been required to revise their writing; and / or have been exposed to instruction, feedback, and assessment practices that focus only on surface considerations. These negative experiences often create fears of and misconceptions about writing and revision (Porte).

Finally, contextual factors such as task difficulty and type (e.g., narrative vs. argumentative), time constraints (e.g., tests), and mode of writing (paperand-pencil or computer) can significantly affect what and how L2 writers revise. Raimes (1987), in a study comparing the writing processes of L2 students when writing for a narrative and for an argumentative task, found that the narrative task led to more planning, rehearsing, revising, and editing. The argumentative task, by contrast, elicited more rescanning and rereading of the assignment. Similarly, Hall (1990) found that transfer of revision skills might depend on the perceived similarity of L1 and L2 tasks, and Matsuhashi and Gordon (1985) caution that the terminology used to instruct students to revise (e.g., add vs. revise) can affect the type of changes that students make in their texts.

The use of the computer as a writing tool can also affect learners' writing and revision practices. It may, for example, alleviate some of the physical obstacles associated with paper-and-pencil writing such as recopying and retranscribing. Moreover, the computer makes it easier to implement such revision processes as text restructuring and reviewing. As Bean (1983) has cautioned, however, although the computer provides a context in which writers are more likely and able to revise, it may affect only the frequency but not the type or level (e.g., local, global) of revisions made. For example, 
Bridwell, Sirc, and Brooke (1985) found no effects for the use of the computer on the revising processes of L1 writers except for an increase in the number of surface-level, typographical changes they made, and more concern with the visual appearance of the text (i.e., layout). Similarly, Van Waes and Schellens (2003) found that in comparison with participants who used pen and paper, those using a word-processor tended to revise more extensively at the beginning of the writing process, but did not normally undertake any systematic revision of their work before finishing. Li (2006), by contrast, reported that the 21 adult Chinese advanced students of English in her study paid more attention to higher-order thinking activities while evaluating their written texts, revised significantly more at most levels, and obtained higher scores in argumentation when they word-processed their essays. The effects of the computer on learners' revision practices may depend on other variables such as time constraints, learners' L2 proficiency, writing expertise, and so forth.

\section{Teaching L2 Learners to Revise Effectively}

Given the findings of research, how can teachers best help L2 learners improve their revision practices? As Witte (1985) has argued, teachers can achieve this goal by helping learners become more skillful at (a) sensing dissonance between their writing goals and meanings and actual texts, and (b) identifying good alternatives to unsatisfactory text (Nold, 1981). In other words, students need to learn what, when, and how to revise. Several instructional practices may help achieve this goal. But first, it is crucial that teachers be aware of the importance of revision for the development of L2 learners' thinking and writing and for the creation of quality writing (Reynolds \& Bonk, 1996). By reviewing theories and research on revision, this article draws attention to the importance of teaching revision skills in the L2 writing classroom.

Second, teachers need to motivate students; discuss their revision practices and beliefs; and address misconceptions about when, how, and what to revise. Teachers should create a positive classroom environment where students feel safe and trusting in order to become ready to reveal the weaknesses in their writing to a peer or a teacher (Dornyei, 2001; Hyland, 2002; Zemelman \& Daniels, 1988). Also, students need to know that they can learn from their mistakes and that effort in the form of revision will help them improve their writing and thinking as well as the quality of their texts (Calkins, 1994). To address misconceptions about revision, teachers can, for example, discuss with their students the differences between skilled and unskilled revisers as presented above. Finally, Elbow (1996) suggests another strategy to promote student motivation in the writing classroom: that teachers actually like their students' writing. Elbow argues that people need first to like their texts in order to improve them, because "only if we like what we 
write will we write again and again by choice - which is the only way we get better" (p. 210). Students who do not like their texts are less likely to revise them. The role of the teacher is critical in this process, because "[students] learn to like [their] writing when [they] have a respected reader who likes it. Therefore, it's the mark of good teachers to like students and their writing" (p. 211).

Third, teachers need to model for their students effective revision strategies-such as self-evaluating text success, reacting to one's own text as a reader, reordering and substituting information, and refining text content and form - as well as demonstrating how to coordinate and monitor the use of these strategies (Chenoweth, 1987; Devine, 1993; Hyland, 2002; Zemelman \& Daniels, 1988). Teachers should provide extensive instruction, practice, and assistance with these strategies until students can apply them independently. Zimmerman and Kitsantas (2002), for example, show how process modeling can enhance the revision practices and self-regulatory skills of L1 writers. Similarly, Sengupta (2000) demonstrates how explicit instruction in revision and discourse-related skills can improve L2 learners' writing performance. Teachers can, for example, tell their students about their personal experience of learning to write and revise, think aloud while composing and revising a piece of writing in front of students, or reformulate a student's draft and then discuss how they did the reformulation and what made it better (Calkins, 1994; van Gelderen, 1997; Zemelman \& Daniels, 1988).

Fourth, teachers should raise students' awareness about the importance of (re) seeing their texts from the reader's perspective (Johns, 1996; Hyland, 2002; Reid, 1989; Rubin, 1998). Strategies to help students develop audience awareness include discussing L2 audience expectations and how they differ from those of L1 readers, using reader think-aloud protocols of students' texts, and encouraging students to imagine readers' attributes and to use those attributes both in creating hypothetical rhetorical contexts and in assessing their own texts accordingly (Beach \& Liebman-Kleine, 1986; Ferris \& Hedgcock, 1998; Johns, 1996; Reid, 1989). Asking students to share their writing with authentic audiences such as peers can also heighten their awareness about what can go wrong in the transmission of ideas from writer to reader (Stanley, 1992; van Gelderen, 1997). Finally, extensive reading can help raise students' awareness about the conventions of L2 texts and about L2 readers' expectations for topic organization and development (Ferris \& Hedgcock; Hyland).

Fifth, teachers should encourage students to reflect on and self-assess their own writing. As Myers (2001) has shown, encouraging students to reflect on their texts and their writing processes can help them to identify their strengths, weaknesses, and learning needs in writing; to become more conscious of their writing processes; and to achieve autonomy (compare 
Cumming, 2006). To encourage self-reflection and assessment, teachers can, for example, use reflective questions and revision checklists to direct students' attention to specific aspects of revision in relation to their texts; provide example texts against which learners can compare their L2 texts; encourage students to apply discussions of writing quality to their own texts; or help them develop and discuss (with teacher and peers) specific assessment criteria for each piece they write (Foster, 1996; Huot, 2002; Zemelman \& Daniels, 1988).

Finally, teachers should use appropriate writing tasks and activities for teaching and assessment. Writing tasks should be purposeful and provide a meaningful context and a clear sense of a (real or imaginary) audience (Reid, 1993). Such tasks are more likely to motivate students, help them develop audience awareness, and provide criteria against which they can evaluate and revise their texts. In addition, teachers need to teach students how to interpret and respond to writing tasks. As for assessment, teachers should use formative evaluation procedures such as portfolios, where the focus is on the writing process and on growth over a period rather than on the final product (Zemelman \& Daniels, 1988). Such procedures are more likely to help students develop self-reflection and revision skills (Hamp-Lyons \& Condon, 2000).

\section{Conclusion}

To be able to revise effectively, L2 learners need to be aware of their writing goals and audiences, master the linguistic and rhetorical aspects of L2 writing, and learn to reflect on their writing and to use appropriate writing strategies flexibly. In other words, they need to attain what Victori (1999) calls meta-knowledge: knowledge about themselves as writers (personal knowledge), knowledge about the task of writing in general (task knowledge), and knowledge about the strategies appropriate for successful task completion (strategic knowledge) in interaction with the specific demands of a given task. Most important, learners need to see revision as a recursive process that permeates the whole writing endeavor. As Witte (1985) explains, expert writers start thinking about their texts-what information to include and how to organize their ideas-even before they commit themselves to writing. As teachers we should direct students' attention to these strategies, model effective revision processes for them, and encourage more frequent and flexible strategy use in order to improve their revision skills and their L2 writing processes and outcomes. This article provides a menu of potentially useful insights and suggestions from which teachers can select according to their actual priorities and concerns and in keeping with the characteristics, needs, and diversity of their students. 


\section{Acknowledgments}

The author thanks Alister Cumming and Ibtissem Knouzi for their comments and suggestions on an earlier version of this article.

\section{The Author}

Khaled Barkaoui is a doctoral candidate in second-language education in the University of Toronto. He has taught EFL reading and writing to university students in Tunisia for three years.

His research interests include second-language writing, second-language assessment, and English for academic purposes.

\section{References}

Bartlett, E.J. (1982). Learning to revise: Some component processes. In M. Nystrand (Ed.), What writers know: The language, process, and structure of written discourse (pp. 345-363). New York: Academic Press.

Beach, R., \& Liebman-Kleine, J. (1986). The writing/reading relationship: Becoming one's own best reader. In B.T. Petersen (Ed.), Convergences: Transactions in reading and writing (pp. 64-81). Urbana, IL: National Council of Teachers of English.

Bean, J.C. (1983). Computerized word-processing as an aid to revision. College Composition and Communication, 34(2), 146-148.

Bridwell, L., Sirc, G., \& Brooke, R. (1985). Revising and computing: Case studies of student writers. In S.W. Freedman (Ed.), The acquisition of written language: Response and revision (pp. 172-194). Norwood, NJ: Ablex.

Calkins, L.M. (1994). The art of teaching writing (2nd ed.). Portsmouth, NH: Heinemann.

Chenoweth, N.A. (1987). The need to teach rewriting. ELT Journal, 41(1), 25-29.

Chenoweth, N.A., \& Hayes, J.R. (2001). Fluency in writing: Generating text in L1 and L2. Written Communication, 18(1), 80-98.

Cumming, A. (Ed.). (2006). Goals for academic writing: ESL students and their instructors. Amsterdam: John Benjamins.

Daiute, C. (1985). Do writers talk to themselves? In S.W. Freedman (Ed.), The acquisition of written language: Response and revision (pp. 133-159). Norwood, NJ: Ablex.

Devine, J. (1993). The role of metacognition in second language reading and writing. In J.G. Carson \& I. Leki (Eds.), Reading in the composition classroom: Second language perspectives (pp. 105-127). Boston, MA: Heinle \& Heinle.

Dornyei, Z. (2001). Teaching and researching motivation. New York: Longman.

Elbow, P. (1996). Ranking, evaluating, and liking: Sorting out three forms of judgment. In B. Leeds (Ed.), Writing in a second language: Insights from first and second language teaching and research (pp. 200-214). New York: Longman.

Faigley, L., \& Witte, S. (1981). Analyzing revision. College Composition and Communication, 32(4), 400-414.

Ferris, D., \& Hedgcock, J.S. (1998). Teaching ESL composition: Purpose, process, and practice. Mahwah, NJ: Erlbaum.

Foster, G. (1996). Student self-assessment: A powerful process for helping students revise their writing. Markham, ON: Pembroke.

Hall, C. (1990). Managing the complexity of revising across languages. TESOL Quarterly, 24, 43-60.

Hamp-Lyons, L., \& Condon, W. (2000). Assessing the portfolio: Principles for practice, theory, and research. Cresskill, NJ: Hampton.

Hayes, J.R., Flower, L., Schriver, K.A., Stratman, J.F., \& Carey, L. (1987). Cognitive processes in revision. In S. Rosenberg (Ed.), Advances in applied psycholinguistics. Vol. 2: Reading, writing, and language learning (pp. 176-240). Cambridge, UK: Cambridge University Press. 
Horwitz, E.K. (1999). Cultural and situational influences on foreign language learners' beliefs about language learning: A review of BALLI studies. System, 27, 557-576.

Huot, B. (2002). (Re)Articulating writing assessment for teaching and learning. Logan, UT: Utah University Press.

Hyland, K. (2002). Teaching and researching writing. Toronto, ON: Longman.

Johns, A.M. (1996). The ESL student and the revision process: Some insights from schema theory. In B. Leeds (Ed.), Writing in a second language: Insights from first and second language teaching and research (pp. 137-145). New York: Longman.

Kobayashi, H., \& Rinnert, C. (2001). Factors relating to EFL writers' discourse level revision skills. International Journal of English Studies, 1(2), 71-101.

Krashen, S.D. (1984). Writing: Research, theory and applications. New York: Pergamon Institute of English.

Li, J. (2006). The mediation of technology in ESL writing and its implications for writing assessment. Assessing Writing 11(1), 5-21.

Matsuhashi, A., \& Gordon, E. (1985). Revision, addition, and the power of the unseen text. In S.W. Freedman (Ed.), The acquisition of written language: Response and revision (pp. 226-249). Norwood, NJ: Ablex.

Myers, J.L. (2001). Self-evaluations of the "stream of thought" in journal writing. System, 29(4), 481-488.

Nold, E.W. (1981). Revising. In C.H. Frederiksen \& J.F. Dominic (Eds.), Writing: The nature, development, and teaching of written communication. Vol. 2, Writing: Process, development and communication (pp. 67-79). Hillsdale, NJ: Erlbaum.

Piolat, A. (1997) Writers' assessment and evaluation of their texts. In C. Clapham \& D. Corson (Eds.), Encyclopaedia of language and education. Vol. 7: Language testing and assessment (pp. 189-198). Dordrecht, Netherlands: Kluwer Academic.

Porte, G. (1996). When writing fails: How academic context and past learning experiences shape revision. System, 24(1), 107-116.

Porte, G. (1997). The etiology of poor second language writing: The influence of perceived teacher preferences on second language revision strategies. Journal of Second Language Writing, 6(1), 61-78.

Raimes, A. (1987). Language proficiency, writing ability, and composing strategies: A study of ESL college student writers. Language Learning, 37(3), 439-468.

Reid, J.M. (1989). English as a second language composition in higher education: The expectations of the academic audience. In D.M. Johnson \& D.H. Roen (Eds.), Richness in writing: Empowering ESL students (pp. 220-234). New York: Longman.

Reid, J.M. (1993). Teaching ESL writing. Englewood Cliffs, NJ: Prentice Hall Regents.

Reynolds, T.H., \& Bonk, C.J. (1996). Facilitating college writers' revisions within a generative-evaluative computerized prompting framework. Computers and Composition, 13(1), 93-108.

Roca De Larios, J., Murphy, L., \& Marin, J. (2002). A critical examination of L2 writing process research. In S. Ransdell \& M.L. Barbier (Eds.), New directions for research in L2 writing (pp. 11-47). Dordrecht, Netherlands: Kluwer Academic.

Rubin, D. (1998). Writing for readers: The primacy of audience in composing. In N. Nelson \& R. Calfee (Eds.), The reading-writing connection (pp. 53-73). Chicago, IL: National Society for the Study of Education.

Scardamalia M., \& Bereiter, C. (1987). Knowledge telling and knowledge transforming in written composition. In S. Rosenberg (Ed.), Advances in applied psycholinguistics. Vol. 2: Reading, writing, and language learning (pp. 142-175). Cambridge, UK: Cambridge University Press.

Schriver, K.A. (1990). Evaluating text quality: The continuum from text-focused to reader-focused methods. Technical Report No. 41. Berkley, CA: University of California Centre for the Study of Writing

TESL CANADA JOURNAL/REVUE TESL DU CANADA

VOL. 25, NO 1, WINTER 2007 
Sengupta, S. (2000). An investigation into the effects of revision strategy instruction on L2 secondary school learners. System, 28(1), 97-113.

Silva, T. (1992). L1 and L2 writing: ESL graduate students' perceptions. TESL Canada Journal, 10(1), 27-46.

Sommers, N. (1996). Revision strategies of student writers and experienced adult writers. In B. Leeds (Ed.), Writing in a second language: Insights from first and second language teaching and research (pp. 128-136). New York: Longman.

Stanley, J. (1992). Coaching student writers to be more effective peer evaluators. Journal of Second Language Writing, 1(3), 217-233.

van Gelderen, A. (1997). Elementary students' skills in revising: Integrating quantitative and qualitative analysis. Written Communication, 14(3), 360-397.

Van Waes, L.V., \& Schellens, P.J. (2003). Writing profiles: The effect of the writing mode on pausing and revision patterns of experienced writers. Journal of Pragmatics, 35(6), 829-853.

Victori, M. (1999). An analysis of writing knowledge in EFL composing: A case study of two effective and two less effective writers. System, 27, 537-555.

Wallace, D.L., \& Hayes, J.R.(1991). Redefining revision for freshmen. Research in the Teaching of English, 25(1), 54-66

Witte, S.P. (1985). Revising, composing theory, and research design. In S.W. Freedman (Ed.), The acquisition of written language: Response and revision (pp. 250-284). Norwood, NJ: Ablex. Zamel, V. (1982). Writing: The process of discovering meaning. TESOL Quarterly, 16, 195-209.

Zemelman, S., \& Daniels, H. (1988). A community of writers: Teaching writing in the junior and senior high school. Portsmouth, NH: Heinemann.

Zimmerman, B.J., \& Bandura, A. (1994). Impact of self-regulatory influences on writing course attainment. American Educational Research Journal, 31(4), 845-862.

Zimmerman, B.J., \& Kitsantas, A. (2002). Acquiring writing revision and self-regulatory skill through observation and emulation. Journal of Educational Psychology, 94(4), 660-668. 